Article

\title{
Sustainability Practices and Stability in the Insurance Industry
}

\author{
Laura Chiaramonte ${ }^{1}$, Alberto Dreassi ${ }^{2, *}(\mathbb{C})$, Andrea Paltrinieri ${ }^{3}\left(\mathbb{D}\right.$ and Stefano Piserà ${ }^{3,4}$ \\ 1 Department of Business Administration, University of Verona, 37129 Verona, Italy; \\ laura.chiaramonte@univr.it \\ 2 Department of Economics, Business, Mathematics and Statistics, University of Trieste, 34123 Trieste, Italy \\ 3 Department of Economics and Statistics, University of Udine, 33100 Udine, Italy; \\ andrea.paltrinieri@uniud.it (A.P.); pisera.stefano@spes.uniud.it (S.P.) \\ 4 Department of Accounting Finance and Management, University of Essex, Colchester CO4 3SQ, UK \\ * Correspondence: adreassi@units.it
}

Received: 3 June 2020; Accepted: 3 July 2020; Published: 8 July 2020

check for updates

\begin{abstract}
While the concept of sustainability is receiving growing attention from investors, firms, regulators, and researchers, little is known about its role in the insurance industry. As institutional investors and risk-absorbers from businesses and individuals, insurers adopt an operating model that is more inclined to target long-term objectives; they should be among the firms benefiting the most from engaging in sustainable practices. The existing literature provides evidence of the positive impact of sustainability on commercial stability, but this is the first study to examine this relationship for the insurance sector. Focusing on American listed insurers, we found that sustainability, proxied by Environmental, Social and Governance (ESG) scores, enhances the stability of insurers, and that this relationship is driven by environmental and social dimensions. We did not observe a significant contribution from the governance dimension. Finally, we found a stronger association for life insurers. Our results are shown to be robust to endogeneity, enterprise heterogeneity and potential sample selection biases.
\end{abstract}

Keywords: Environmental Social and Governance (ESG) scores; stability; insurance

\section{Introduction}

Corporate social responsibility (CSR) represents a relatively old field of study, with a significant amount of research having already been conducted [1]. More recently, it has attracted renewed interest due to growing awareness of the role played by sustainability in economic development [2].

In general, most research targets the impact of CSR practices on entrepreneurial performance [3,4]; however, the largest body of research encompasses the nonfinancial sector $[5,6]$, and contributions have only recently extended to banks or investment vehicles [7,8]. Very few papers have examined CSR or the broader concept of sustainability in the insurance sector [9].

The scarcity of academic research is unfortunate. The business model of insurers, both on the liability side (i.e., risk-pooling and mutuality) and on the asset side (i.e., investments), should show a strong link with CSR and environmental, social and governance (ESG) practices [10].

On one hand, while pooling risks, insurers redistribute resources obtained through premiums to policyholders experiencing losses of income or wealth ("social" dimension). On the other hand, the inversion of their operating cycle and its duration enable the use of such resources to fund a great volume of investments in both financial and real markets. Sustainability, therefore, should encompass both environmental and social dimensions on the asset side. Lastly, as financial intermediaries, insurers are subject to deep scrutiny from markets and supervisors regarding their decision-making 
processes (the governance dimension). Therefore, insurers should be among those benefitting the most from engagement in CSR practices.

The aim of this study is to provide the first empirical evidence of a relationship between stability and sustainability in insurance companies, filling a material literature gap. We expect to confirm the general finding of a beneficial impact of CSR on the stability of insurers. By analyzing a balanced sample of 94 companies from 10 American countries, we provide evidence that ESG scores, our proxy for CSR practices, represent a superior accounting-based measure of stability.

When we broke down scores in individual pillars (environmental, social and governance), we found that both environmental and especially social scores drive this relationship, while governance seems to play an insignificant role.

Our results held up to a battery of robustness checks conducted to address endogeneity, potential sample selection bias and the heterogeneity between ESG and non-ESG firms. These additional analyses confirmed our results and provide evidence that the insurance business model is able to foster engagement in social activities. In particular, we also checked if life insurers differ from nonlife insurers, and if this distinction affected our results: we found that the long-term business model of life insurance is more strongly associated with CSR benefits.

Our contribution to the literature is manifold. First, we document for the first time how CSR practices affect insurance stability. Second, we extend the literature on insurance stability to include the CSR dimension and its constituents. Third, we add interesting findings to the literature on ESG as a proxy for CSR. As a main policy implication, regulators and supervisors should consider that, beyond the governance dimension, engagement in social and environmental practices has the potential to provide stability to insurers.

The rest of the paper is structured as follows. Section 2 reviews the literature, deriving our main hypothesis, while Section 3 describes our data and methodology. Section 4 discusses our main results and Section 5 provides additional analyses, focusing on the differences between life and nonlife business lines. Section 6 verifies the robustness of our results. Finally, Section 7 concludes with our policy implications.

\section{Literature Review and Hypotheses}

For the purposes of this paper, the term "sustainability" implies a comprehensive approach to the management of organizations which is focused on creating and maximizing long-term economic, social and environmental value. Since CSR is widely interpreted under the banner of a triple bottom-line approach (i.e., environmental engagement, social engagement and corporate governance), we use these terms as substitutes, despite the former (sustainability) being frequently considered a broader concept [11]. According to [12], "the three-pillar conception of (social, economic and environmental) sustainability [ ... ] has become ubiquitous"; in spite of being developed gradually over several decades in the existing literature, corporate sustainability is rooted in CSR. Early research on CSR investigated its potential impact on the economic performance of nonfinancial firms [3,4]. In general, empirical works [13] and meta-analyses [14] support the existence of a positive relationship. The latter has been investigated in terms of both performance and firm value [5], as well as the stock market and accounting performance of "highly sustainable" firms [15].

More recently, academic research has addressed the link between CSR and different key nonfinancial firm parameters, beyond performance, i.e., the cost of capital [16], the cost of equity [17], credit ratings [18], corporate cash holdings [6], and systematic risk [19]. Finally, new studies are starting to explore how the business environment influences CSR practices [20].

More scarce are contributions focused on the financial sector, where banks are the most widely studied firms. Simpson et al. authored one of the first studies assessing the existence of a relationship between banks' social performance and financial performance [21], while De la Cuesta-González et al. [22] provided evidence that social responsibility has a positive effect on the financial performance of Spanish banks, also reducing their potential risks; the authors of [23] highlighted the important role 
of CSR in promoting economic development through banks, while the authors of [24] observed a positive association between bank reputation and social performance and a negative association with corporate governance and environmental performance. Similar results hold true in emerging markets; most studies have shown a positive relationship between CSR and performance (e.g., the authors of [25] focused on a sample of Indian banks).

Besides performance, the literature on the CSR-risk relationship in banks is even more limited. Few papers have focused on the impact of single CSR aspects on bank risk, such as governance [26,27] and the environment [7], revealing also that improvements in sustainability practices increase stability in US banks [8].

The literature dealing with insurers' CSR practices is in a very early stage. To the best of our knowledge, the most comprehensive analysis was performed in [9]. Through an analysis of 150 institutions from 20 countries, the author found a high level of interfirm and international variability, with social and ethical aspects of CSR being better integrated than environmental aspects. Only a few companies are engaged in environmental risk analyses or have adopted an exclusion strategy for their investments. Engagement in CSR activities is positively correlated with the size of insurance companies, which might be explained by increased attention from stakeholders to company growth [28]. Finally, European insurance companies appear to be more inclined to provide sustainable financial products than entities from other geographical areas [9].

The authors of [29] assessed the impact of ESG disclosures on company profitability, and partially considered insurance, finding that a positive effect is stronger for banks than insurers.

No study, to the best of our knowledge, has considered CSR and the stability of insurers together. To fill this gap, we aim at investigating the effects on insurer risk regarding CSR, proxied by ESG scores, as in most related studies (see [6]). We consider stability to be a relevant and growing field of academic research [30-32] in a sector that plays a major role in enhancing and protecting economic growth while reducing uncertainties for market participants.

We hypothesize that the positive association between ESG and stability also applies in the insurance sector. In particular, the environmental dimension is expected to be significant for insurance companies. According to the International Association of Insurance Supervisors [33], five main risks arise from environmental concerns, affecting underwriting, market, strategic, operational, and reputational risks.

The social dimension is expected to provide benefits, among others, that arise from greater employee satisfaction [8]. In a business relying heavily on human resources, we expect a positive association with stability. Moreover, product responsibility and the orientation toward the public good are also aspects that contribute to the social dimension and should be able to provide even stronger positive effects on stability.

In terms of governance, the literature acknowledges how improvements therein are a key risk management tool [24,34]. However, regulation and supervision already significantly impact this dimension, and, consistent with similar studies on other financial intermediaries, we do not expect to find a significant impact on stability among insurers [27].

Finally, we expect that the strength of this association is greater for life insurers, given their greater focus on the long-term compared to nonlife entities. Sustainability practices are associated with a long-term view on the outcome of related investments; this dimension differs significantly between life and nonlife insurers, and possibly also across individual business lines.

Consistent with [35], we expect this relationship to be driven by three main channels.

The risk-pooling/risk-bearing function of insurers, through the management of underwriting and acquisition costs, adds value to policyholders; greater sensitivity to sustainability should be able to ensure more stability by influencing the design of products, the behavior of distribution networks, the handling of claims, and the redistribution of income/wealth across clients. For example, these practices may reduce litigation costs or lapses arising from misselling.

The second channel comprises services provided by insurers to policyholders, such as financial advice and planning. Engagement in sustainability should lead to higher stability by improving customer retention and the efficacy with which products respond to the protection needs of clients. 
Finally, the intermediation channel should be able to achieve a more stable level of returns through a sustainable selection of investments, both retained by the insurer or shared with policyholders in guaranteed or participating contracts. For example, this could lead to a sustainable design of minimum guaranteed interest rates, or to a reduction in the financial risks borne by policyholders.

\section{Methodology and Data}

\subsection{Empirical Methodology}

To empirically test the effects of CSR engagement, proxied by ESG scores, on insurance firm stability, we use a Pooled Ordinary Least Square (POLS) regression with time and country fixed-effects (FE). The reasons for choosing this methodology were twofold. On one hand, it allows us to examine simultaneously, in a comparative setting, the cross-sectional and time dimensions for a relatively small sample, where some country-based effects may be time-invariant, or a shock may impact all firms in a given year. We follow the methodology employed in [36] to control for cross-sectional panel data heterogeneity. As a precondition for the use of POLS, we confirm the lack of heteroskedasticity by employing the Breusch-Pagan test, which does not reject the null hypothesis of homoskedasticity. Additionally, these models are already widely used in the literature because of these advantages in similar settings $[27,32]$.

More precisely, our econometric specification can be illustrated as follows:

$$
\text { Z-score }_{i, t}=c+\beta_{1} \text { ESG }_{i, t-1}+\sum_{k} \beta_{k} \text { InsuranceControls }_{i, t-1}+\sum_{z} \beta_{z} \text { CountryControls }_{i, t-1}+v_{i}+\delta_{t}+\mu_{i, t}
$$

In Equation (1), Z-score $e_{i, t}$ is the stability measure of insurance firm $i$ at time $t, c$ is a constant term and $v_{i}, \delta_{t}, \mu_{i, t}$ are, respectively, time FE, country FE, and the idiosyncratic error.

Despite the Z-score not being the only stability measure, it is an accounting indicator that is widely employed not only in the banking literature [37,38], but also in the case of insurers [30,32,39]. Despite other stability measures could have been those based on market metrics (for instance, Merton's Distance-to-Default) or on supervisory approaches (such as the available or required/minimum solvency capital) we decided to keep the analysis focused on the Z-score due to its popularity in previous research on the insurance industry.

Higher Z-score values indicate a lower probability of insolvency, and thus, greater stability of a firm.

We obtained our data from Thomson Reuters and independently calculated the Z-score from raw data as the sum of equity to total assets (ETA) and return on average assets (ROAA), scaled by the three-year standard deviation of ROAA ( $\sigma$ ROAA). Since the Z-score is highly skewed, we used its natural logarithm $[40,41]$. Moreover, in order to mitigate the effect of extreme values, we winsorized the Z-score at the $1 \%$ level on both tails.

Engagement in sustainable practices for insurer $i$ at time $t-1$ is proxied by ESG scores. Our variables of interest, furtherly explained in Section 3.3, are represented by ESG scores and their individual pillars (ENV, SOC, and GOV).

Insurance firm risk can be affected by additional firm-specific characteristics as well as by the operating environment. Thus, consistent with studies examining the determinants of insurance firm risk [30,31], we control for a set of insurance-specific factors (InsuranceControls) and country-specific covariates (CountryControls) for insurance firm i at $\mathrm{t}-1$.

More specifically, in the spirit of [31], we include the following firm-specific control variables: the natural logarithm of total premiums to proxy for firm size (SIZE); the ratio of cash and equivalents to total assets as a measure of liquidity (LIQ); the change in net claims incurred to proxy the growth of claims (CLAIMS GRW); the ratio of total debt to equity as a measure for leverage (LEV); the change in net premiums earned to proxy for revenues growth (PREMIUM GRW); and the ratio of underwriting profit to total assets as a measure of profitability (PROFIT).

We also include the following macroeconomic variables: the Herfindahl-Hirschman index to proxy for firm concentration (HHI), the GDP growth (GDP GRW), and the inflation rate (INFL). 
Table 1 defines the variables used in our analysis, their data sources, and their expected signs. To mitigate the effect of extreme values, control variables based on accounting data (SIZE, LIQ, CLAIMS GRW, LEV, PREMIUM GRW, and PROFIT) are winsorized at a 1\% level on both tails.

\subsection{Sample Description}

The analysis focuses on American listed insurers with non-missing values in Thomson Reuters' Refinitiv database (an enhancement and replacement to the Thomson Reuters' ASSET4 ratings, widely used in previous CSR studies (e.g., [42]) for our key variables, i.e., the overall ESG score and its three pillars.

These criteria significantly restrict the size of our sample (94 insurance firms, further details are provided in Table A5 in the Appendix A). There are three main reasons for this outcome. Firstly, there is a very limited set of mandatory nonfinancial disclosure requirements for American insurance firms, especially compared to those in Europe. Additionally, firms can decide not to report ESG scores to the Thomson Reuters' Refinitiv database. Finally, since Thomson Reuters does not specify the reason for missing values on ESG scores, it is not feasible to compare insurance firms that do not disclose this information with those that do, since it would not clearly discriminate CSR-engaged firms from others. However, to alleviate the selection bias which may have occurred due to the criteria used to create our sample, in Section 5 we run specific robustness tests. The results corroborate the conclusion that our analysis is not affected by this bias. Moreover, a typical distinction in studies encompassing the insurance industry is between stock and mutual companies. Unfortunately, our data source did not provide information on mutual insurers, despite their significant role in several markets (f.i. the USA). Nonetheless, it is reasonable to expect that mutual insurers should be, on average, more active with reference to the social pillar, despite the fact that issues could arise in the governance dimension, and that data on their ESG scores is very limited; we are therefore only able to suggest this direction for future research.

We focus our analysis on the American market due to the depth of available data and to limit the potential bias arising from excessively heterogenous, cross-country regulatory and supervisory frameworks. Also, the limited number of mandatory nonfinancial disclosures (i.e., disclosures relying more on the willingness of firms rather than compliance), combined with the global relevance of the American market, provide an ideal setting in which to test our hypothesis.

The data collected are year-end observations over a long period (2006-2018). It was not possible to start the analysis earlier than 2006 due to several missing data on ESG scores in our data source.

\subsection{ESG Target Variables}

Although there is no univocal identification of sustainability, ESG scores have already been extensively used by consulting firms, financial advisors, and asset managers to identify firms' actions addressing CSR engagement.

As widely argued in previous studies [43], ESG score monitoring and disclosures reflect companies' efforts to develop CSR strategies, allowing investors to better identify risks and opportunities. Consistently, CSR engagement is widely proxied by ESG scores in the literature [42].

We collected data on ESG scores from the Thomson Reuters' Refinitiv database. Its granularity allowed us to extend the analysis beyond the composite score, also investigating the contribution of single pillars (ENV, SOC, and GOV) to insurer stability. Table A1 in the Appendix A provides a definition and summarizes the methodology of the Thomson Reuter's Refinitiv ESG scores. All ESG scores range between 0 and 1 , with higher values indicating stronger performance in sustainability practices. However, in unreported robustness checks, we test our baseline assumptions by employing an ESG score aggregated using the Principal Component Analysis (PCA), confirming the strength of results. 
Table 1. Variable definitions and expected results.

\begin{tabular}{|c|c|c|c|}
\hline Variable Name & Definition & Source & Expected Sign \\
\hline Z-score & $\begin{array}{l}\text { Dependent Variable } \\
\text { A widely-used measure employed to predict the probability of default of a } \\
\text { firm, based on accounting data. Higher scores indicate higher stability. It is } \\
\text { computed as the sum of equity to total assets (ETA) and return on average } \\
\text { assets (ROAA), scaled by the three-year standard deviation of the return on } \\
\text { average assets ( } \sigma \text { ROAA). Due to skewness, we use the natural logarithm of } \\
\text { the resulting measure. }\end{array}$ & $\begin{array}{l}\text { Thomson Reuters (raw data) } \\
\text { Authors' calculation of the final variable }\end{array}$ & l \\
\hline ESG & $\begin{array}{c}\text { Target Variables } \\
\text { The Environmental Social Governance (ESG) score is an overall company } \\
\text { score based on self-reported information in the Environmental (ENV), } \\
\text { Social (SOC), and corporate Governance (GOV) pillars. }\end{array}$ & \multirow{3}{*}{$\begin{array}{l}\text { Thomson Reuters } \\
\text { See the Appendix for further details }\end{array}$} & Positive \\
\hline SOC & $\begin{array}{l}\text { The Environmental score is an overall company score based on the weighted } \\
\text { average of self-reported information in the Resource Use score, } \\
\text { Emissions score, and Environmental Innovation score. } \\
\text { The Social score is an overall company score based on the weighted average of } \\
\text { self-reported information in the Workforce score, Human rights score, } \\
\text { Community score and Product Responsibility score. }\end{array}$ & & Positive \\
\hline GOV & $\begin{array}{l}\text { The Governance score is an overall company score based on the weighted } \\
\text { average of self-reported information in the Management score, } \\
\text { Shareholders score, Corporate Social Responsibility (CSR) Strategy score. }\end{array}$ & & Positive \\
\hline \multicolumn{4}{|c|}{ Insurance Controls } \\
\hline SIZE & Natural logarithm of total premium. & \multirow{6}{*}{$\begin{array}{l}\text { Thomson Reuters (raw data) } \\
\text { Authors' calculation of the final variable }\end{array}$} & Positive/Negative \\
\hline LIQ & Cash and equivalents to total assets. & & Negative \\
\hline CLAIMS GRW & Change in net claims incurred. & & Positive/Negative \\
\hline LEV & Total debt to equity. & & Negative \\
\hline PREMIUM GRW & Change in net premium earned. & & Positive/Negative \\
\hline PROFIT & Underwriting profit to total assets. & & Positive \\
\hline \multicolumn{4}{|c|}{ Country Controls } \\
\hline HHI & $\begin{array}{l}\text { The HHI is calculated as the sum of the squared market share value (in term of } \\
\text { total assets) of all insurance firms in the country. }\end{array}$ & $\begin{array}{l}\text { Thomson Reuters (raw data) } \\
\text { Authors' calculation of the final variable }\end{array}$ & Positive \\
\hline $\begin{array}{l}\text { GDP GRW } \\
\text { INFL }\end{array}$ & $\begin{array}{c}\text { Annual change of Gross Domestic Product (GDP). } \\
\text { Annual inflation rate. }\end{array}$ & World Bank Financial Development & $\begin{array}{l}\text { Positive/Negative } \\
\quad \text { Negative }\end{array}$ \\
\hline
\end{tabular}


Firstly, in order to explore the overall effects of CSR practices on insurer stability (our first hypothesis), we employed the ESG composite score (ESG). We expected to find a positive association with our dependent variable (Z-score), i.e., higher ESG scores were expected to be linked with more stable insurance activities, consistent with a long-term perspective and within the stakeholder-based view.

Additionally, following our main hypothesis, we repeated our analysis by breaking down ESG scores into individual pillars. As widely recognized in the literature [44], each ESG component has its own identity, and contributes differently to firms' performance and risks.

In order to visualize the overall behavior of ESG scores and stability for our sample period and firms, Figure 1 provides time-series graphs. They show, in general, more similarities between the overall ESG score and the ENV pillar, and the Z-score. These CSR proxies seemed to anticipate the response of the Z-score until 2013 (falling or growing approximately one year in advance). From 2014 on, instead, CSR proxies experienced an upward break and maintained relative stability despite the fall in Z-score shown for 2017 and 2018. The SOC pillar showed some differences, gaining higher levels between 2009 and 2010 and then experiencing a fall not seen for the Z-score. More recently, SOC and the Z-score seem more closely related, including the fall experienced in 2017 and 2018. The GOV pillar, instead, showed a more stable upward trend, until more stable scores were achieved after 2015; these continuous gains in governance matters may be related to the strengthening of prudential supervision enforced as a response to the financial crisis, whereas ENV and SOC, as well as their impact on the overall ESG score, seemed to be more closely related with the CSR strategies of insurers.

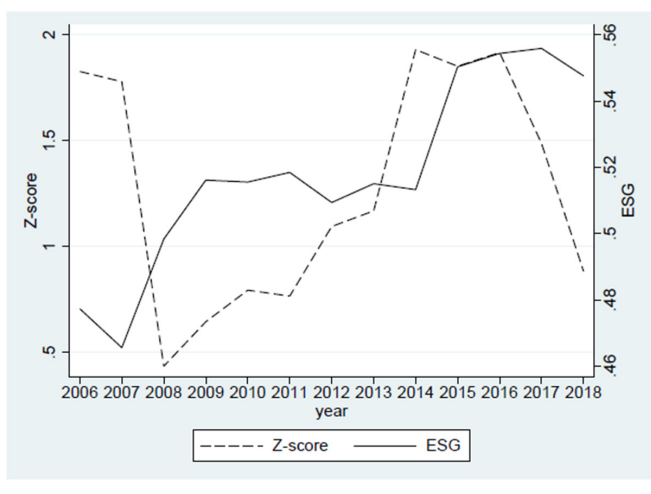

(a)

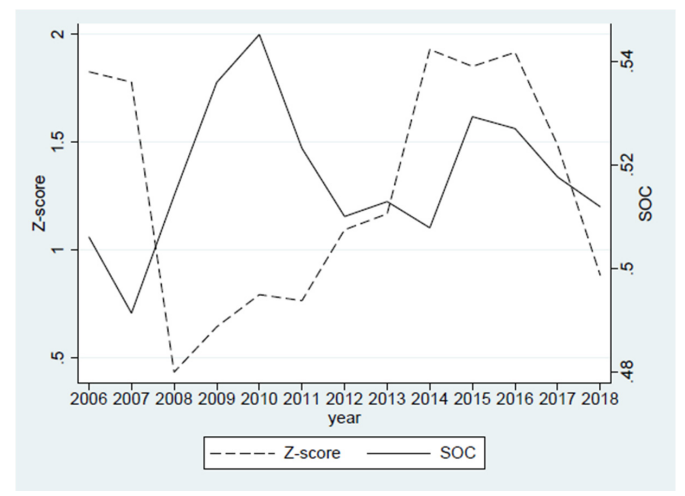

(c)

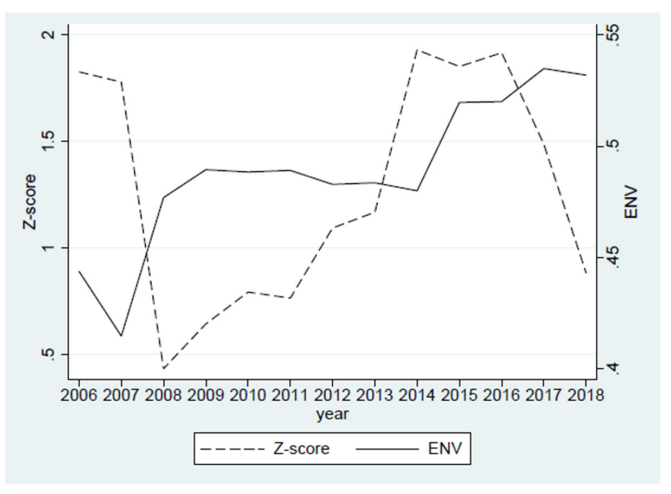

(b)

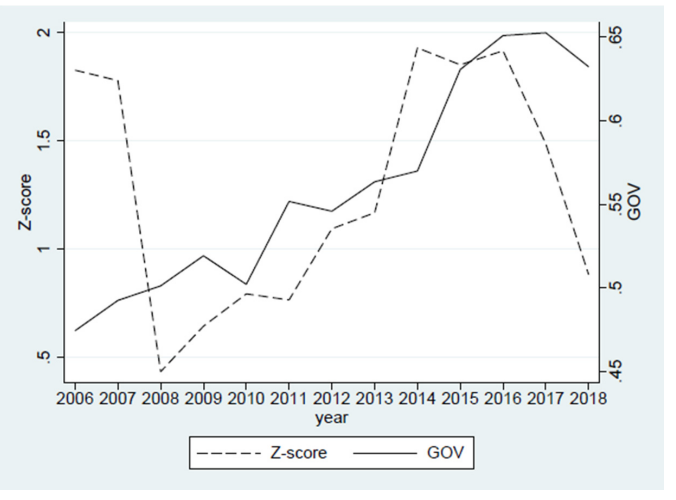

(d)

Figure 1. Time series of ESG scores and stability of insurers. (a) Compares the mean Z-score and ESG score; (b) Compares the mean Z-score and ENV score; (c) Compares the mean Z-score and SOC score; (d) Compares the mean Z-score and GOV score.

In the next section, we implemented our methodological approach in order to examine this relationship in depth and in a robust manner. 
These figures show the relationship between the mean Z-score (our dependent variable), as a proxy of stability for sampled insurers, and the CSR proxies (our target variables: the ESG score and its three components, ENV, SOC, and GOV), over the period 2006-2018. Variable definitions are provided in Table 1 . The Z-score is winsorized at the $1 \%$ of each tail.

\section{Main Results}

Table 2 reports the results of the baseline model (Equation (1)); our dependent variable is the Z-score, and the target variables are the composite ESG score and its ENV, SOC, and GOV pillars.

Table 2. Baseline model.

\begin{tabular}{|c|c|c|c|c|}
\hline \multirow{2}{*}{ Variables } & \multicolumn{4}{|c|}{ Z-Score } \\
\hline & (I) & (II) & (III) & (IV) \\
\hline ESG $(-1)$ & $\begin{array}{l}0.618 * \\
(0.374)\end{array}$ & & & \\
\hline $\operatorname{ENV}(-1)$ & & $\begin{array}{l}0.605^{* *} \\
(0.300)\end{array}$ & & \\
\hline $\operatorname{SOC}(-1)$ & & & $\begin{array}{l}0.878^{* * *} \\
(0.328)\end{array}$ & \\
\hline GOV $(-1)$ & & & & $\begin{array}{l}-0.360 \\
(0.265)\end{array}$ \\
\hline SIZE $(-1)$ & $\begin{array}{l}-0.039 \\
(0.052)\end{array}$ & $\begin{array}{l}-0.046 \\
(0.052)\end{array}$ & $\begin{array}{l}-0.058 \\
(0.052)\end{array}$ & $\begin{array}{c}0.018 \\
(0.045)\end{array}$ \\
\hline $\operatorname{LIQ}(-1)$ & $\begin{array}{l}-4.025 * * * \\
\quad(1.118)\end{array}$ & $\begin{array}{l}-4.172 * * * \\
\quad(1.112)\end{array}$ & $\begin{array}{l}-3.910 * * * \\
(1.113)\end{array}$ & $\begin{array}{l}-4.431^{* * *} \\
(1.123)\end{array}$ \\
\hline CLAIMS GRW (-1) & $\begin{array}{l}-0.070 \\
(0.062)\end{array}$ & $\begin{array}{l}-0.061 \\
(0.061)\end{array}$ & $\begin{array}{l}-0.076 \\
(0.061)\end{array}$ & $\begin{array}{l}-0.055 \\
(0.061)\end{array}$ \\
\hline $\operatorname{LEV}(-1)$ & $\begin{array}{c}-0.303^{* * *} \\
(0.108)\end{array}$ & $\begin{array}{l}-0.329^{* * *} \\
(0.107)\end{array}$ & $\begin{array}{l}-0.312^{* * * *} \\
(0.105)\end{array}$ & $\begin{array}{l}-0.224^{* *} \\
(0.105)\end{array}$ \\
\hline PREMIUM GRW (-1) & $\begin{array}{c}0.027 \\
(0.243)\end{array}$ & $\begin{array}{c}0.019 \\
(0.243)\end{array}$ & $\begin{array}{c}-0.0034 \\
(0.239)\end{array}$ & $\begin{array}{l}-0.032 \\
(0.243)\end{array}$ \\
\hline PROFIT (-1) & $\begin{array}{l}-0.304 \\
(0.370)\end{array}$ & $\begin{array}{l}-0.227 \\
(0.366)\end{array}$ & $\begin{array}{l}-0.359 \\
(0.370)\end{array}$ & $\begin{array}{l}-0.203 \\
(0.378)\end{array}$ \\
\hline HHI (-1) & $\begin{array}{c}1.347 \\
(3.745)\end{array}$ & $\begin{array}{c}1.161 \\
(3.667)\end{array}$ & $\begin{array}{l}1.426 \\
(3.788)\end{array}$ & $\begin{array}{c}1.803 \\
(3.738)\end{array}$ \\
\hline GDP GRW (-1) & $\begin{array}{l}-0.650 \\
(1.204)\end{array}$ & $\begin{array}{l}-0.657 \\
(1.199)\end{array}$ & $\begin{array}{l}-0.554 \\
(1.203)\end{array}$ & $\begin{array}{l}-0.569 \\
(1.246)\end{array}$ \\
\hline $\operatorname{INFL~}(-1)$ & $\begin{array}{l}5.781 \\
(9.465)\end{array}$ & $\begin{array}{c}6.211 \\
(9.565)\end{array}$ & $\begin{array}{l}5.884 \\
(9.456)\end{array}$ & $\begin{array}{c}6.080 \\
(9.720)\end{array}$ \\
\hline Time FE & Yes & Yes & Yes & Yes \\
\hline Country FE & Yes & Yes & Yes & Yes \\
\hline Robust SE & Yes & Yes & Yes & Yes \\
\hline N. of obs. & 453 & 453 & 453 & 454 \\
\hline R-squared & 0.244 & 0.247 & 0.251 & 0.243 \\
\hline
\end{tabular}

Note: The superscripts ${ }^{* * *}, * *$, and ${ }^{*}$ denote coefficients statistically different from zero at the $1 \%, 5 \%$, and $10 \%$ levels, respectively, in two-tailed tests.

As expected, we found that the overall ESG score and the ENV and SOC pillars were associated with a reduction in insurer risks. The outcome was different for the GOV pillar, where we did not find a statistically significant relationship.

Despite the lack of literature, our baseline results are in line with findings stressing the relationship between ESG and risk [18], but we fill the gap for the insurance industry. Moreover, our baseline results confirm the guidelines of [33] regarding the importance of environmental awareness for insurance firms. At the same time, the pillar leading the positive relationship between sustainable practices and insurer risk is the SOC score (the coefficient takes the value of 0.88 , compared to the 0.60 found for SOC and the 0.62 for the overall ESG score). 
From our literature review [35], we attribute these results to the three main channels that describe business models of insurers. Firstly, sensitivity towards environmental and social activities provides more stability through the risk-pooling/risk bearing function, i.e., product design, underwriting, the management of and incentives to distribution networks, claims handling procedures and redistribution of income/wealth through indemnities and benefits are activities that, above all, benefit from a stakeholder-oriented view of the firm. Secondly, insurers provide advice and planning services to policyholders and can obtain more stable relationships by embedding environmental and social considerations when addressing the needs of customers. Lastly, by intermediating policyholders' premiums on real and financial markets, insurers including environmental and social considerations in their products should provide more sustainable investment returns, especially when these are shared with clients.

The fact that governance is not driving a response in the Z-score is not surprising, due to the significant strengthening of prudential supervision in financial markets, including the insurance sector, as a response to the 2007-2008 financial crisis. This does not mean that investments in governance do not provide a reduction of risk. In the investigated period, we observed an increase in regulatory measures and firms' responses to governance-related issues, but these were not significantly associated with a direct response in our independent variable.

Finally, with reference to the control variables, we found that only LIQ and LEV were significant in explaining insurance stability. More specifically, the negative sign for our proxy for liquidity (i.e., cash to total assets) was in line with the findings of [31], suggesting that a liquidity risk may arise from an increase in net claims, and thus, may significantly affect the insolvency risk. Furthermore, our results confirm, for the insurance sector, the general association between higher leverage and risks. More precisely, in line with previous studies [45], insurers with lower financial leverage are more likely to be given a higher credit rating. Consistently, Reference [46] also stresses a negative relationship between leverage and the capital structure of insurers.

Unlike other firms, however, insurer liabilities are mainly driven by policy obligations (technical provisions), an actuarial conservative estimate. The nature and behavior of these liabilities is different from those of financial debt, representing uncertain and illiquid future outflows contingent on the occurrence of a claim or benefit.

\section{Additional Analysis: Life and Nonlife Insurance}

The insurance business takes a substantially different form if we consider providers of life or nonlife insurance coverage. Life and nonlife insurers show significant divergence on the level and behavior of their leverage, consistent with the contractual risks that are underwritten. In particular, life insurers per se show higher leverage, due to the typically longer duration of their policies, and bear a more direct link between assets and liabilities through participating or guaranteed contracts. We further explored this specific aspect, specifically addressing this potential source of heterogeneity in our sample.

There were two reasons to perform this additional analysis. On one hand, material differences exist between the business model of life and nonlife insurers, leading to significant divergence among the variables used to describe their behavior. Additionally, one could expect that the life insurance business model, by being more extended to the long term, should be more closely related to CSR activities.

One of the leading ways to reduce this possible bias is to employ a propensity score matching (PSM) procedure [47], to allow a more robust comparison to be made of the association between CSR engagement and insurer risk between life and nonlife entities (Table 3).

To identify the control group, we first ran a logit model (Panel A of Table 3) to calculate propensity scores using, as the dependent covariate, the dummy variable D_LIFE, equaling 1 if a firm is labelled as a Life insurer according to the Thomson Reuters Business category classification, and 0 otherwise. We also included the full set of firm-level control variables in our regressions, including fixed effects, as presented in our baseline estimation [48]. 
Table 3. Propensity Score Matching: life and nonlife insurance.

\begin{tabular}{|c|c|c|c|c|}
\hline \multicolumn{5}{|c|}{ Panel A: Logit Model-Identifying Propensity Scores } \\
\hline \multicolumn{3}{|c|}{ Variables } & \multicolumn{2}{|l|}{ D_LIFE } \\
\hline \multicolumn{3}{|c|}{ SIZE $(-1)$} & \multicolumn{2}{|l|}{-0.014} \\
\hline \multicolumn{3}{|c|}{$\operatorname{LIQ}(-1)$} & $\begin{array}{r}-7.269 * * \\
(1.834)\end{array}$ & \\
\hline \multicolumn{3}{|c|}{ CLAIMS GRW (-1) } & \multicolumn{2}{|c|}{$\begin{array}{l}-0.0783 \\
(0.0898)\end{array}$} \\
\hline \multicolumn{3}{|c|}{$\operatorname{LEV}(-1)$} & \multicolumn{2}{|c|}{$\begin{array}{c}1.601^{* * *} \\
(0.200)\end{array}$} \\
\hline \multicolumn{3}{|c|}{ PREMIUM GRW (-1) } & 0.167 & \\
\hline \multicolumn{3}{|c|}{ PROFIT $(-1)$} & \multicolumn{2}{|c|}{$\begin{aligned}-1.549 & (0.371)\end{aligned}$} \\
\hline \multicolumn{3}{|c|}{ Time FE } & \multicolumn{2}{|c|}{ Yes } \\
\hline \multicolumn{3}{|c|}{ Country FE } & \multicolumn{2}{|l|}{ Yes } \\
\hline \multicolumn{3}{|c|}{ Robust SE } & \multicolumn{2}{|l|}{ Yes } \\
\hline \multicolumn{3}{|c|}{ N. of obs. } & \multicolumn{2}{|l|}{1081} \\
\hline \multicolumn{3}{|c|}{ Pseudo R-Squared } & \multicolumn{2}{|l|}{0.298} \\
\hline \multicolumn{5}{|c|}{ Panel B: Univariate Statistics_Effectiveness of Matching } \\
\hline Variables & Life (1) & Nonlife (2) & Difference (1)-(2) & $p$-values \\
\hline SIZE & 14.236 & 14.544 & -0.307 & 0.270 \\
\hline LIQ & 0.021 & 0.018 & 0.003 & 0.312 \\
\hline CLAIMS GRW & 0.115 & 0.180 & -0.065 & 0.172 \\
\hline LEV & 1.050 & 1.020 & 0.030 & 0.246 \\
\hline PREMIUM GRW & 0.060 & 0.062 & -0.002 & 0.570 \\
\hline PROFIT & 0.169 & 0.174 & -0.005 & 0.110 \\
\hline \multicolumn{5}{|c|}{ Panel C: Propensity Score Matching (PSM) for Life vs. Nonlife } \\
\hline & \multicolumn{4}{|c|}{ Z-score } \\
\hline Variables & (I) & (II) & (III) & (IV) \\
\hline ESG $(-1)$ & $\begin{array}{l}1.424^{* *} \\
(0.666)\end{array}$ & & & \\
\hline $\operatorname{ENV}(-1)$ & & $\begin{array}{l}1.145^{* *} \\
(0.501)\end{array}$ & & \\
\hline $\operatorname{SOC}(-1)$ & & & $\begin{array}{c}2.152 * * * \\
(0.593)\end{array}$ & \\
\hline GOV $(-1)$ & & & & $\begin{array}{l}-0.657 \\
(0.421)\end{array}$ \\
\hline Controls $(-1)$ & Yes & Yes & Yes & Yes \\
\hline Time FE & Yes & Yes & Yes & Yes \\
\hline Country FE & Yes & Yes & Yes & Yes \\
\hline Robust SE & Yes & Yes & Yes & Yes \\
\hline N. of obs. & 171 & 171 & 171 & 171 \\
\hline R-squared & 0.644 & 0.647 & 0.663 & 0.647 \\
\hline
\end{tabular}

Note: The superscripts ${ }^{* *}$ and ${ }^{* *}$ denote coefficients statistically different from zero at the $1 \%$ and $5 \%$ levels, respectively, in two-tailed tests.

We then matched, without replacement, each treated firm to a control firm using the Caliper distance of 5\%. As shown in Panel B of Table 3, we found no significant difference between targets and their matching nontargets, suggesting that our matching approach identified matching firms that were very similar to treatment firms, reducing firms' controls differences and possible related biases.

Finally, Panel C of Table 3 shows the results of our regression model after the matching procedure, confirming the robustness of our baseline results. The ESG scores remained positively associated with a high Z-score, even after reducing the potential heterogeneity bias of our sample, again confirming our baseline results. Again, the ENV and (especially) SOC pillars are the drivers of this relationship, whereas we did not find evidence of a role played by governance. 
On top of underlining the robustness of our baseline results, this additional analysis allowed us to argue for the presence of another interesting association between CSR activities and firms' risks in the insurance sector. By definition, CSR is associated with a long-term view of the firm, extending from shareholders to the overall pool of stakeholders of the firm. On the other hand, life insurers adopt a business model that is very often oriented to long-term insurance risks, as well as intermediate funds with longer holding periods. As hypothesized in this study, therefore, we expected to find a clearer relationship for life insurers, where the intermediation and service channels are stronger than for nonlife entities. In other words, we confirm that stronger benefits between ESG scores and firms' risk were found when a long-term view was present, and it seems that the life insurance business model enhanced this association.

\section{Robustness Tests}

To test the validity of our baseline results, we ran a set of robustness checks addressing endogeneity issues, namely, potential sample selection biases (through a Heckman two-step method), reverse causality, omitted variables and measurement error (through an IV-2SLS estimator), and a bias arising from heterogeneity between ESG and non-ESG firms driving our results (through a PSM procedure). All these robustness checks are summarized in Table 4. We also tested if our results were driven by the choice of the methodological setting producing ESG scores by adopting an alternative measure encompassing both engagement in sustainability and the conduct of firms, proxies by controversies related to CSR practices (Table 5).

Being based on a nonrandomly selected sample, our results may have been subjected to a sample selection bias [49]. Table 4 provides the results of the Heckman two-step method [50,51], following this procedure. We estimated the decision equation using a multinomial probit model (Table A2 in the Appendix A), whose parameters were used to calculate the Inverse Mills Ratio (IMR); the latter is included as an additional explanatory variable in the performance equation. The results from the second step of the Heckman model relied on the strength and unbiasedness of our baseline regression, stressing the significant and positive role of ESG scores and their components in enhancing insurance firms' risk reduction. The lack of statistical significance of the IMR confirms that our baseline results were not affected by selection problems.

Other sources of endogeneity could have affected the positive link between sustainable insurance firms' practices and financial stability. Specifically, we verified the robustness of our results stemming from reverse causality, omitted variables, and measurement errors by employing the instrumental variables (IV) two-stage least squares (2SLS) estimator [6,27]. For the IV 2SLS, the first stage F-test (see Table A3 in the Appendix A) reports the goodness of fit as instrumental variables of the average yearly and business line values of our target variables $[18,27]$. The coefficients of our target variables (ESG, ENV, SOC, and GOV) confirm our baseline findings, even when controlling for these endogeneity concerns.

Lastly, we controlled for potential biases deriving from the heterogeneity among ESG and non-ESG firms by employing Propensity Score Matching (PSM) on the basis of all covariates proceeding as follow; to identify the control group, we first ran a logit model (Panel A of Table A4 in the Appendix A) to calculate propensity scores using the dummy variable D_ESG (identifying ESG insurer). We employed the set of firm-level control variables in our regressions, including fixed effects in our baseline estimation [48]. We then matched, without replacement, each treated firm to a control firm using the Caliper distance of 5\%. As shown in Panel B (Table A4 in the Appendix A), we found no significant differences between targets and their matching nontargets, suggesting that our matching approach identified matching firms that were very similar to treatment firms, thereby reducing controls differences and related possible biased. This method, widely applied in empirical research, allowed us to remove differences between treatment and nontreatment groups [52] and to obtain a balanced and comparable sample. For our purposes, firms with ESG scores may have statistically significant differences compared to non-ESG firms, allowing them to perform better in terms of financial stability. 
Employing the PSM allowed us to obtain a sample of matching firms with similar financial conditions, and to better estimate the relevance of ESG scores as well as of their ENV, SOC, and GOV pillars. As shown in Table 4, we confirm our baseline results.

The only difference arising from this setting is the lower magnitude of the coefficient associated with the SOC pillar. It could be argued that by matching insurers through covariates, we observed more consistent behavior among firms in terms of their social engagement. In other words, it seems that covariates were able to capture some variations within the insurance business model (e.g., linked to business lines and products, underwriting processes, distribution channels) that enhance each firm's engagement in the SOC pillar. Then, some firms obtained higher scores and were associated with lower risks, but the overall distance was reduced. This was not true for the ENV pillar and the overall ESG score.

As a further check, we tested the consistency of our results using an additional ESG score definition, provided by Thomson Reuters Refinitiv: the ESG Combined score (ESG Comb). This measure considers both the ESG practices of firms and controversies related to them. According to Thomson Reuters Refinitiv, the ESG Combined score "overlays the ESG Score with ESG controversies to provide a comprehensive evaluation on the company's sustainability impact and conduct in near real time". The main aim of this score is to discount the ESG performance score based on negative media stories related to bad practices or scandals. For firms involved in ESG controversies, the ESG Comb score corresponds to the weighted average of the ESG Scores and ESG Controversies Score per fiscal period, with recent controversies being reflected in the latest completed period. In contrast, if a company was not involved in any controversies, the ESG Comb score was equal to the ESG Score. As shown in Table 5, the ESG combined score was statistically and positively correlated to Z-score, confirming the robustness of our baseline findings.

As for any firm, the stability of insurance companies is significantly affected by the operating environment $[31,32]$. Therefore, we ran a series of tests to determine under which condition the ESG scores could be considered as an effective risk mitigating strategy. Due to the construction of our sample, a residual source of heterogeneity potentially influencing our results arose from the presence of observations from ten American countries.

Therefore, our first test involved categorizing firms based on whether they operate in a highly concentrated business environment or not (Panel A of Table 6). We found that our baseline results were valid for insurance firms operating in highly concentrated markets (above the median value of HHI).

The issue of market concentration is not limited to the insurance sector; this is a concern that has been attracting academic research for decades [53]. Our results may seem counterintuitive; more concentrated markets are less competitive and, therefore, should see fewer incentives to engage in CSR activities. However, consistent with [39], we argue that more concentrated insurance markets are associated with lower financial stability and, therefore, are also more able to manifest the positive effects of CSR engagement for entities that are more sensitive to a stakeholder-oriented view of the firm.

Our second test considers the level of inflation (INFL) as a possible moderator affecting the positive relationship between ESG scores and the Z-score (Panel B of Table 6). We checked this by splitting our sample into two groups: firms with headquarters in countries that are subject to high inflation rates (above the median value of inflation rate) compared to firms in low inflation rate countries. Our results showed that ESG scores were effective in enhancing insurance firms' risk reduction only in countries with low inflation rates.

Inflation matters in the insurance sector for several reasons; above all, (i) protecting the purchasing power of savings is a key driver of several life insurance products, and (ii) price instability affects the sustainability of nonlife insurance through indemnities being delayed compared to premium collection. Additionally, we argue that since lower levels of inflation are usually able to discriminate between advanced and emerging countries, this result underlines the notion that sustainable growth, rather than growth itself, represents a greater focus of mature markets, and should therefore deliver more benefits to insurers that are active in that environment. 
Table 4. Robustness checks: endogeneity concerns.

\begin{tabular}{|c|c|c|c|c|c|c|c|c|c|c|c|c|}
\hline \multirow{2}{*}{ Variables } & \multicolumn{4}{|c|}{ Heckman } & \multicolumn{4}{|c|}{ IV 2SLS } & \multicolumn{4}{|c|}{ PSM } \\
\hline & (I) & (II) & (III) & (IV) & (I) & (II) & (III) & (IV) & (I) & (II) & (III) & (IV) \\
\hline ESG $(-1)$ & $\begin{array}{l}0.801 * * \\
(0.400)\end{array}$ & & & & $\begin{array}{l}3.803^{* *} \\
(1.900)\end{array}$ & & & & $\begin{array}{l}1.050^{* *} \\
(0.521)\end{array}$ & & & \\
\hline $\operatorname{ENV}(-1)$ & & $\begin{array}{c}0.888^{* * *} \\
(0.312)\end{array}$ & & & & $\begin{array}{l}2.800 * * \\
(1.200)\end{array}$ & & & & $\begin{array}{c}0.828^{* *} \\
(0.382)\end{array}$ & & \\
\hline SOC $(-1)$ & & & $\begin{array}{c}0.952 \text { ** } \\
(0.373)\end{array}$ & & & & $\begin{array}{c}3.201^{* * *} \\
(1.000)\end{array}$ & & & & $\begin{array}{c}0.141^{* *} \\
(0.055)\end{array}$ & \\
\hline GOV (-1) & & & & $\begin{array}{l}-0.402 \\
(0.201)\end{array}$ & & & & $\begin{array}{l}-4.490 \\
(4.220)\end{array}$ & & & & $\begin{array}{r}0.246 \\
(0.421\end{array}$ \\
\hline Controls $(-1)$ & Yes & Yes & Yes & Yes & Yes & Yes & Yes & Yes & Yes & Yes & Yes & Yes \\
\hline Time FE & Yes & Yes & Yes & Yes & Yes & Yes & Yes & Yes & Yes & Yes & Yes & Yes \\
\hline Country FE & Yes & Yes & Yes & Yes & Yes & Yes & Yes & Yes & Yes & Yes & Yes & Yes \\
\hline Robust SE & Yes & Yes & Yes & Yes & Yes & Yes & Yes & Yes & Yes & Yes & Yes & Yes \\
\hline N. of obs. & 568 & 568 & 568 & 568 & 453 & 453 & 453 & 453 & 548 & 548 & 548 & 548 \\
\hline R-squared & & & & & 0.110 & 0.150 & 0.172 & 0.162 & 0.322 & 0.314 & 0.346 & 0.284 \\
\hline IMR & $\begin{array}{c}0.010 \\
(0.0341)\end{array}$ & $\begin{array}{c}0.088 \\
(0.338)\end{array}$ & $\begin{array}{c}0.074 \\
(0.341)\end{array}$ & $\begin{array}{c}0.015 \\
(0.064)\end{array}$ & & & & & & & & \\
\hline Sargan $p$-value & & & & & 0.191 & 0.100 & 0.104 & 0.210 & & & & \\
\hline
\end{tabular}

Note: The superscripts ${ }^{* * *}$ and ${ }^{* *}$ denote coefficients statistically different from zero at the $1 \%$ and $5 \%$ levels, respectively, in two-tailed tests.

Table 5. Robustness check: alternative ESG score definition.

\begin{tabular}{cc}
\hline Variables & Z-Score \\
\hline ESG Comb $(-1)$ & $1.501^{* * *}$ \\
& $(0.301)$ \\
Controls $(-1)$ & Yes \\
Time FE & Yes \\
Country FE & Yes \\
Robust SE & Yes \\
N. of obs. & 453 \\
R-squared & 0.265 \\
\hline
\end{tabular}

Note: The superscript ${ }^{* * *}$ denotes a coefficient statistically different from zero at the $1 \%$ level in two-tailed tests. 
Table 6. Baseline model for different subsamples.

\begin{tabular}{|c|c|c|c|c|c|c|c|c|}
\hline \multicolumn{9}{|c|}{ Panel A: Level of Industry Concentration } \\
\hline \multirow[t]{3}{*}{ Variables } & \multicolumn{8}{|c|}{ Z-Score } \\
\hline & \multicolumn{4}{|c|}{ Above Median HHI } & & \multicolumn{2}{|c|}{ Below Median HHI } & \multirow[b]{2}{*}{ (IV) } \\
\hline & (I) & (II) & (III) & (IV) & (I) & (II) & (III) & \\
\hline ESG (-1) & $\begin{array}{c}1.401 * * \\
(0.600)\end{array}$ & & & & $\begin{array}{c}0.500 \\
(0.403)\end{array}$ & & & \\
\hline $\operatorname{ENV}(-1)$ & & $\begin{array}{l}1.000 \text { * } \\
(0.601)\end{array}$ & & & & $\begin{array}{c}0.713 \\
(0.632)\end{array}$ & & \\
\hline $\operatorname{SOC}(-1)$ & & & $\begin{array}{r}1.702 * * * \\
(0.600)\end{array}$ & & & & $\begin{array}{c}0.621 \\
(0.324)\end{array}$ & \\
\hline GOV $(-1)$ & & & & $\begin{array}{c}0.201 \\
(0.303)\end{array}$ & & & & $\begin{array}{l}-0.501 \\
(0.301)\end{array}$ \\
\hline Controls $(-1)$ & Yes & Yes & Yes & Yes & Yes & Yes & Yes & Yes \\
\hline Time FE & Yes & Yes & Yes & Yes & Yes & Yes & Yes & Yes \\
\hline Country FE & Yes & Yes & Yes & Yes & Yes & Yes & Yes & Yes \\
\hline Robust SE & Yes & Yes & Yes & Yes & Yes & Yes & Yes & Yes \\
\hline N. of obs. & 126 & 126 & 126 & 126 & 327 & 327 & 327 & 327 \\
\hline R-squared & 0.423 & 0.472 & 0.498 & 0.454 & 0.225 & 0.233 & 0.227 & 0.228 \\
\hline \multicolumn{9}{|c|}{ Panel B: Level of inflation } \\
\hline \multirow{3}{*}{ Variables } & \multicolumn{7}{|c|}{ Z-score } & \\
\hline & \multicolumn{4}{|c|}{ Above Median INFLATION } & \multicolumn{4}{|c|}{ Below Median Inflation } \\
\hline & (I) & (II) & (III) & (IV) & (I) & (II) & (III) & (IV) \\
\hline ESG (-1) & $\begin{array}{c}0.165 \\
(0.518)\end{array}$ & & & & $\begin{array}{l}0.916^{*} \\
(0.503)\end{array}$ & & & \\
\hline $\operatorname{ENV}(-1)$ & & $\begin{array}{c}0.178 \\
(0.499)\end{array}$ & & & & $\begin{array}{l}0.948^{* *} \\
(0.367)\end{array}$ & & \\
\hline $\operatorname{SOC}(-1)$ & & & $\begin{array}{c}0.451 \\
(0.483)\end{array}$ & & & & $\begin{array}{l}1.100^{* *} \\
(0.442)\end{array}$ & \\
\hline GOV $(-1)$ & & & & $\begin{array}{l}-0.171 \\
(0.389)\end{array}$ & & & & $\begin{array}{l}-0.534 \\
(0.352)\end{array}$ \\
\hline Controls $(-1)$ & Yes & Yes & Yes & Yes & Yes & Yes & Yes & Yes \\
\hline Time FE & Yes & Yes & Yes & Yes & Yes & Yes & Yes & Yes \\
\hline Country FE & Yes & Yes & Yes & Yes & Yes & Yes & Yes & Yes \\
\hline Robust SE & Yes & Yes & Yes & Yes & Yes & Yes & Yes & Yes \\
\hline N. of obs. & 168 & 168 & 168 & 168 & 285 & 285 & 285 & 285 \\
\hline R-squared & 0.348 & 0.358 & 0.360 & 0.358 & 0.295 & 0.297 & 0.297 & 0.286 \\
\hline
\end{tabular}

Note: The superscripts ${ }^{* * *}, * *$ and * denote coefficients statistically different from zero at the $1 \%, 5 \%$, and $10 \%$ levels, respectively, in two-tailed tests 


\section{Conclusions}

The aim of this paper is to assess how CSR engagement, proxied by ESG scores, reduces insurers' risks, through a strongly balanced sample of 94 listed insurance companies from 2006 to 2018 from ten American countries.

For the first time, we empirically documented the role played by sustainability practices among insurers in reducing accounted-based probabilities of default. We also disentangled this relationship in individual ESG pillars and provided a battery of additional analysis and robustness tests to confirm our results.

We found that the overall ESG scores were positively associated with insurer stability, and that this relationship was significant for the environmental and, especially, the social pillars. We did not find significant outcomes for the governance dimension, and attributed this result to the growing regulatory and supervisory attention being paid to these specific issues across the investigated sample period.

We provided evidence that our results are robust to typical endogeneity concerns through a series of additional analyses. These checks allowed us to characterize the usual difference between life and nonlife insurers, showing that life entities received a stronger benefit regarding stability from engagement in CSR practices, consistent with a stronger role played by the services and intermediation channels concerning risk pooling/risk taking, compared to nonlife insurers.

Moreover, our propensity score matching strategy allowed us to argue that a greater sensitivity to the social dimension is closely related with the insurance business model in general, but that further increases in stability are associated with higher levels of engagement. At the same time, the environmental dimension remains strongly related with more stability, whereas governance does not provide significant results.

Finally, we showed that our results were stronger for firms operating in more concentrated markets, supporting the positive role of CSR engagement in environments usually associated with more fragile insurance firms, and in countries with lower inflation, consistent with those being more mature markets which more actively seek both growth and sustainability.

Therefore, this paper supports the stakeholder theory for insurers in terms of the positive association between sustainability and stability.

The leading policy implication arising from our study, material for insurance firms as well as investors, points to a positive response to CSR engagement of firms' risks. Moreover, regulators and supervisors should consider how, beyond the governance dimension, engagement in social and environmental practices is able to deliver greater stability to insurance companies. In this sense, the discussion is ongoing in Europe within the European supervisory authorities (including the insurance sector). Moreover, for the banking sector, in 2019, the European Banking Authority started to consider if and how ESG factors could be incorporated into the regulatory and supervisory framework. A similar path could be beneficial for the insurance sector, as well as in countries outside Europe.

However, we are aware of a few limitations in our approach. Despite the extensive sample period that we analyzed, the number of observations was limited, since they relied on data that were available only for listed firms. Moreover, we were not able to further break down our main results at the business line level. Also, given the quality and depth of data, we had to limit our investigation to a life/nonlife company level. Similarly, again due to data constraints, we were not able to employ firm-level controls that could grasp the specific role played by the different transmission channels that are identified in the existing literature.

Finally, we suggest that future empirical research should encompass testing the response of profitability and efficiency in a similar setting.

Author Contributions: Conceptualization, L.C., A.D., A.P. and S.P.; Data curation, L.C., A.D., A.P. and S.P.; Formal analysis, L.C., A.D., A.P. and S.P.; Investigation, L.C., A.D., A.P. and S.P.; Methodology, L.C., A.D., A.P. and S.P.; Project administration, L.C., A.D., A.P. and S.P.; Resources, L.C., A.D., A.P. and S.P.; Software, L.C., A.D., A.P. and S.P.; Supervision, L.C., A.D., A.P. and S.P.; Validation, L.C., A.D., A.P. and S.P.; Visualization, L.C., A.D., A.P. and S.P.; Writing - original draft, L.C., A.D., A.P. and S.P.; Writing - review \& editing, L.C., A.D., A.P. and S.P. All authors have read and agreed to the published version of the manuscript.

Funding: This research received no external funding.

Conflicts of Interest: The authors declare no conflict of interest. 


\section{Appendix A}

Table A1. Calculation of ESG scores and its components. This table summarizes category scores and the weights used by Thomson Reuters' Refinitiv database to compute the ESG score and its three components (ENV, SOC, and GOV).

\begin{tabular}{|c|c|c|c|c|c|c|c|c|c|c|}
\hline Pillars & \multicolumn{3}{|c|}{ 1. Environmental Score (ENV) } & \multicolumn{4}{|c|}{ 2. Social Score (SOC) } & \multicolumn{3}{|c|}{ 3. Governance Score (GOV) } \\
\hline Categories & $\begin{array}{l}\text { Resource Use } \\
\text { score } \\
\text { Reflects a } \\
\text { company's } \\
\text { performance } \\
\text { and capacity to } \\
\text { reduce the use } \\
\text { of materials, } \\
\text { energy or water, } \\
\text { and to find more } \\
\text { eco-efficient } \\
\text { solutions by } \\
\text { improving } \\
\text { supply chain } \\
\text { management. }\end{array}$ & $\begin{array}{c}\text { Emissions score } \\
\text { Measures a } \\
\text { company's } \\
\text { commitment } \\
\text { and } \\
\text { effectiveness } \\
\text { towards } \\
\text { reducing } \\
\text { environmental } \\
\text { emission in the } \\
\text { production and } \\
\text { operational } \\
\text { processes. }\end{array}$ & $\begin{array}{l}\text { Innovation score } \\
\text { Reflects a } \\
\text { company's } \\
\text { capacity to } \\
\text { reduce the } \\
\text { environmental } \\
\text { costs and } \\
\text { burdens for its } \\
\text { customers, and } \\
\text { thereby creating } \\
\text { new market } \\
\text { opportunities } \\
\text { through new } \\
\text { environmental } \\
\text { technologies } \\
\text { and processes or } \\
\text { eco-designed } \\
\text { products. }\end{array}$ & $\begin{array}{l}\text { Workforce score } \\
\text { Measures a } \\
\text { company's } \\
\text { effectiveness } \\
\text { towards job } \\
\text { satisfaction, } \\
\text { healthy and safe } \\
\text { workplace, } \\
\text { maintaining } \\
\text { diversity and } \\
\text { equal } \\
\text { opportunities, } \\
\text { and } \\
\text { development } \\
\text { opportunities } \\
\text { for its } \\
\text { workforce. }\end{array}$ & $\begin{array}{c}\text { Human Rights } \\
\text { score } \\
\text { Measures a } \\
\text { company's } \\
\text { effectiveness } \\
\text { towards } \\
\text { respecting the } \\
\text { fundamental } \\
\text { human rights } \\
\text { conventions. }\end{array}$ & $\begin{array}{l}\text { Community } \\
\text { score } \\
\text { Measures the } \\
\text { company's } \\
\text { commitment } \\
\text { towards being a } \\
\text { good citizen, } \\
\text { protecting } \\
\text { public health } \\
\text { and respecting } \\
\text { business ethics. }\end{array}$ & $\begin{array}{l}\text { Product Resp. } \\
\text { score } \\
\text { Reflects a } \\
\text { company's } \\
\text { capacity to } \\
\text { produce quality } \\
\text { goods and } \\
\text { services } \\
\text { integrating the } \\
\text { customer's } \\
\text { health and } \\
\text { safety, integrity, } \\
\text { and data } \\
\text { privacy. }\end{array}$ & $\begin{array}{l}\text { Management } \\
\text { score } \\
\text { Measures a } \\
\text { company's } \\
\text { commitment } \\
\text { and } \\
\text { effectiveness } \\
\text { towards } \\
\text { following best } \\
\text { practice } \\
\text { corporate } \\
\text { governance } \\
\text { principles. }\end{array}$ & $\begin{array}{l}\text { Shareholders } \\
\text { score } \\
\text { Measures a } \\
\text { company's } \\
\text { effectiveness } \\
\text { towards equal } \\
\text { treatment of } \\
\text { shareholders } \\
\text { and the use of } \\
\text { anti-takeover } \\
\text { devices. }\end{array}$ & $\begin{array}{l}\text { CSR Strategy } \\
\text { score } \\
\text { Reflects a } \\
\text { company's } \\
\text { practices to } \\
\text { communicate } \\
\text { that it integrates } \\
\text { the economic } \\
\text { (financial), } \\
\text { social and } \\
\text { environmental } \\
\text { dimensions into } \\
\text { its day-to-day } \\
\text { decision-making } \\
\text { processes. }\end{array}$ \\
\hline Indicators & 19 & 22 & 20 & 29 & 8 & 14 & 12 & 34 & 12 & 8 \\
\hline Total & \multicolumn{10}{|c|}{178} \\
\hline Weights & $\begin{array}{c}0.110 \\
(=19 / 178)\end{array}$ & $\begin{array}{c}0.120 \\
(=22 / 178)\end{array}$ & $\begin{array}{c}0.110 \\
(=20 / 178)\end{array}$ & $\begin{array}{c}0.160 \\
(=29 / 178)\end{array}$ & $\begin{array}{c}0.045 \\
(=8 / 178)\end{array}$ & $\begin{array}{c}0.080 \\
(=14 / 178)\end{array}$ & $\begin{array}{c}0.070 \\
(=12 / 178)\end{array}$ & $\begin{array}{c}0.190 \\
(=34 / 178)\end{array}$ & $\begin{array}{c}0.070 \\
(=12 / 178)\end{array}$ & $\begin{array}{c}0.045 \\
(=8 / 178)\end{array}$ \\
\hline Total & \multicolumn{3}{|c|}{0.3400} & \multicolumn{4}{|c|}{0.3550} & \multicolumn{3}{|c|}{0.3050} \\
\hline $\begin{array}{c}\text { New } \\
\text { Weights }\end{array}$ & $\begin{array}{c}0.3235 \\
(=0.110 / 0.340)\end{array}$ & $\begin{array}{c}0.3529 \\
(=0.120 / 0.340)\end{array}$ & $\begin{array}{c}0.3235 \\
(=0.110 / 0.340)\end{array}$ & $\begin{array}{c}0.4507 \\
(=0.160 / 0.3550)\end{array}$ & $\begin{array}{c}0.1268 \\
(=0.045 / 0.3550)\end{array}$ & $\begin{array}{c}0.2254 \\
(=0.080 / 0.3550)\end{array}$ & $\begin{array}{c}0.1972 \\
(=0.070 / 0.3550)\end{array}$ & $\begin{array}{c}0.6230 \\
(=0.190 / 0.3050)\end{array}$ & $\begin{array}{c}0.2295 \\
(=0.070 / 0.3050)\end{array}$ & $\begin{array}{c}0.1475 \\
(=0.045 / 0.3050)\end{array}$ \\
\hline $\begin{array}{l}\text { Calculation } \\
\text { of scores }\end{array}$ & \multicolumn{3}{|c|}{$\begin{array}{c}\text { ENV }= \\
\text { Resource Use score } \times 0.3235+\text { Emission score } \times 0.3529 \\
+ \text { Environmental Innovation score } \times 0.3235\end{array}$} & \multicolumn{4}{|c|}{$\begin{array}{c}\text { SOC }= \\
\text { Workforce score } \times 0.4507+\text { Human Rights score } \times 0.1268 \\
+ \text { Community score } \times 0.2254+\text { Product Responsibility score } \times 0.1972\end{array}$} & \multicolumn{3}{|c|}{$\begin{array}{c}\mathrm{GOV}= \\
\text { Management score } \times 0.6230+\text { Shareholders score } \times \\
0.2295 \\
+ \text { CSR Strategy score } \times 0.1475\end{array}$} \\
\hline
\end{tabular}


Table A2. First step of the Heckman model. This table shows the results of the first step estimation of the Heckman model (see Table 4) by showing the decision equation using a multinomial probit model, whose parameters are used to calculate the Inverse Mills Ratio (IMR). In this setting the dependent variables are dummies (DESG, DENV, DSOC, and DGOV) equal to 1 from the year in which a sampled firm started to be involved in ESG practices; and 0 in previous years. Variable definitions are provided in Table 1. All nonbinary independent variables are lagged by one year with respect to the dependent variable. The variables based on accounting data (SIZE, LIQ, CLAIMS GRW, LEV, PREMIUM GRW, and PROFIT) are winsorized at the $1 \%$ of each tail. Time and Country fixed-effects (FE) are included in all specifications. Robust standard errors (SE) are reported in parentheses. The superscripts ***,**, and * denote coefficients statistically different from zero at the $1 \%, 5 \%$, and $10 \%$ levels, respectively, in two-tailed tests.

\begin{tabular}{|c|c|c|c|c|}
\hline Variables & $\begin{array}{l}\text { DESG } \\
\text { (I) }\end{array}$ & $\begin{array}{l}\text { DENV } \\
\text { (II) }\end{array}$ & $\begin{array}{l}\text { DSOC } \\
\text { (III) }\end{array}$ & $\begin{array}{l}\text { DGOV } \\
\text { (IV) }\end{array}$ \\
\hline SIZE $(-1)$ & $\begin{array}{l}1.682 * * * \\
(0.162)\end{array}$ & $\begin{array}{l}1.682^{* * *} \\
(0.162)\end{array}$ & $\begin{array}{c}1.682^{* * *} \\
(0.162)\end{array}$ & $\begin{array}{l}1.682^{* * *} \\
(0.162)\end{array}$ \\
\hline LIQ (-1) & $\begin{array}{l}3.655^{* *} \\
(1.547)\end{array}$ & $\begin{array}{c}3.655^{* *} \\
(1.547)\end{array}$ & $\begin{array}{l}3.655^{* *} \\
(1.547)\end{array}$ & $\begin{array}{l}3.655^{* *} \\
(1.547)\end{array}$ \\
\hline CLAIMS GRW (-1) & $\begin{array}{c}0.040 \\
(0.121)\end{array}$ & $\begin{array}{c}0.040 \\
(0.121)\end{array}$ & $\begin{array}{c}0.040 \\
(0.121)\end{array}$ & $\begin{array}{c}0.040 \\
(0.121)\end{array}$ \\
\hline $\operatorname{LEV~}(-1)$ & $\begin{array}{c}-0.671 * \\
(0.354)\end{array}$ & $\begin{array}{c}-0.671 \text { * } \\
(0.354)\end{array}$ & $\begin{array}{c}-0.671 \text { * } \\
(0.354)\end{array}$ & $\begin{array}{c}-0.671 \text { * } \\
(0.354)\end{array}$ \\
\hline PREMIUM GRW (-1) & $\begin{array}{c}-0.697^{* *} \\
(0.353)\end{array}$ & $\begin{array}{c}-0.697^{* *} \\
(0.353)\end{array}$ & $\begin{array}{c}-0.697^{* *} \\
(0.353)\end{array}$ & $\begin{array}{l}-0.697^{* *} \\
(0.353)\end{array}$ \\
\hline PROFIT (-1) & $\begin{array}{l}-3.525^{* * *} \\
(0.607)\end{array}$ & $\begin{array}{l}-3.525^{* * *} \\
(0.607)\end{array}$ & $\begin{array}{l}-3.525 * * * \\
(0.607)\end{array}$ & $\begin{array}{l}-3.525 * * * \\
(0.607)\end{array}$ \\
\hline $\mathrm{HHI}(-1)$ & $\begin{array}{l}-5.357 \\
(4.258)\end{array}$ & $\begin{array}{l}-5.357 \\
(4.258)\end{array}$ & $\begin{array}{l}-5.357 \\
(4.258)\end{array}$ & $\begin{array}{l}-5.357 \\
(4.258)\end{array}$ \\
\hline GDP GRW (-1) & $\begin{array}{c}2.899 \\
(3.462)\end{array}$ & $\begin{array}{c}2.899 \\
(3.462)\end{array}$ & $\begin{array}{c}2.899 \\
(3.462)\end{array}$ & $\begin{array}{c}2.899 \\
(3.462)\end{array}$ \\
\hline INFL (-1) & $\begin{array}{l}-16.14 \\
(22.01)\end{array}$ & $\begin{array}{l}-16.14 \\
(22.01)\end{array}$ & $\begin{array}{l}-16.14 \\
(22.01)\end{array}$ & $\begin{array}{l}-16.14 \\
(22.01)\end{array}$ \\
\hline Time FE & Yes & Yes & Yes & Yes \\
\hline Country FE & Yes & Yes & Yes & Yes \\
\hline Robust SE & Yes & Yes & Yes & Yes \\
\hline N. of obs. & 994 & 994 & 994 & 994 \\
\hline R-squared & 0.581 & 0.581 & 0.581 & 0.581 \\
\hline
\end{tabular}

Table A3. First stage of the IV 2SLS estimator. This table shows the results of the first stage estimation of IV 2SLS model (see Table 4), where we instrument each target variable (the ESG score and its three components) with its yearly and industry average [16], showing their correlations and goodness (the Cragg-Donald weak instruments F-test statistics) with reference to the original target variable being instrumented. The reference variables for the first stage are: ESG, ENV, SOC, and GOV in columns (I), (II), (III), (IV), respectively. The dependent variable is the Z-score, measuring the stability of insurers. Variable definitions are provided in Table 1 . All nonbinary independent variables are lagged by one year with respect to the dependent variable. The variables based on accounting data (Z-score, SIZE, LIQ, CLAIMS GRW, LEV, PREMIUM GRW, and PROFIT) are winsorized at the $1 \%$ of each tail. Time and Country fixed-effects (FE) are included in all specifications. Robust standard errors (SE) are reported in parentheses. The superscripts ${ }^{* * *}, * *$, and ${ }^{*}$ denote coefficients statistically different from zero at the $1 \%$, $5 \%$, and $10 \%$ levels, respectively, in two-tailed tests.

\begin{tabular}{ccccc}
\hline Variables & (I) & (II) & Z-Score & \\
\hline Instruments for: & $0.757^{* * *}$ & & & \\
ESG & $(0.099)$ & & \\
& & & \\
\end{tabular}


Table A3. Cont.

\begin{tabular}{ccccc}
\hline \multirow{2}{*}{ Variables } & (I) & (II) & (III) & (IV) \\
\hline ENV & & $0.670^{* * *}$ & & \\
SOC & $(0.074)$ & & \\
& & & $0.848^{* * *}$ & \\
GOV & & $(0.084)$ & \\
& & & & $0.453^{*}$ \\
Controls (-1) & Yes & Yes & Yes & Yes \\
Time FE & Yes & Yes & Yes & Yes \\
Country FE & Yes & Yes & Yes & Yes \\
Robust SE & Yes & Yes & Yes & Yes \\
N. of obs. & 526 & 526 & 526 & 526 \\
R-squared & 0.528 & 0.592 & 0.553 & 0.177 \\
F-Cragg Donald & $22.60 * * *$ & $40.00^{* * *}$ & $27.45^{* * *}$ & $19.00^{* * *}$ \\
test & & & & \\
\hline
\end{tabular}

Table A4. Implementation of PSM model. This table provides the first two steps of the Propensity Score Matching (see Table 4). Panel A presents the results of the logit regression aiming at finding propensity scores. In Equation (A1) the dependent variable D_ESG is equal 1 if the ESG score of a insurance firm is greater than 0; and 0 otherwise. The control variables (SIZE, LIQ, CLAIMS GRW, LEV, PREMIUM GRW, and PROFIT) are winsorized at $1 \%$ of each tail. The sample period observed is 2006-2018. Time and Country fixed effects (FE) are included in all specifications. Firm robust standard errors (SE) are reported in parentheses. The matching, without replacement, is achieved using the Caliper distance of 5\%. Panel B compares mean statistics for our Propensity Score Matching (PSM) samples between firms with ESG (D_ESG=1) and other firms, with the purpose of verifying the effectiveness of the matching approach. The superscripts ${ }^{* *},{ }^{* *}$, and $*$ denote coefficients statistically different from zero at the $1 \%$, $5 \%$, and $10 \%$ levels, respectively, in two-tailed tests.

\begin{tabular}{ccccc}
\hline \multicolumn{5}{c}{ Panel A: Logit Model-Identifying Propensity Scores } \\
\hline & DESG & DENV & DSOC & DGOV \\
\cline { 2 - 5 } Variables & $\mathbf{( I )}$ & $\mathbf{( I I )}$ & $\mathbf{( I I I )}$ & (IV) \\
\hline SIZE (-1) & $0.908^{* * *}$ & $0.908^{* * *}$ & $0.908^{* * *}$ & $0.908^{* * *}$ \\
& $(0.0514)$ & $(0.0514)$ & $(0.0514)$ & $(0.0514)$ \\
LIQ (-1) & $2.144^{* *}$ & $2.144^{* *}$ & $2.144^{* *}$ & $2.144^{* *}$ \\
& $(0.854)$ & $(0.854)$ & $(0.854)$ & $(0.854)$ \\
CLAIMS GRW (-1) & 0.0250 & 0.0250 & 0.0250 & 0.0250 \\
& $(0.0801)$ & $(0.0801)$ & $(0.0801)$ & $(0.0801)$ \\
LEV (-1) & $-0.388^{* * *}$ & $-0.388^{* * *}$ & $-0.388^{* * *}$ & $-0.388^{* * *}$ \\
& $(0.127)$ & $(0.127)$ & $(0.127)$ & $(0.127)$ \\
PREMIUM GRW (-1) & $-0.766^{* * *}$ & $-0.766^{* * *}$ & $-0.766^{* * *}$ & $-0.766^{* * *}$ \\
& $(0.217)$ & $(0.217)$ & $(0.217)$ & $(0.217)$ \\
PROFIT (-1) & $-2.122^{* * *}$ & $-2.122^{* * *}$ & $-2.122^{* * *}$ & $-2.122^{* * *}$ \\
& $(0.341)$ & $(0.341)$ & $(0.341)$ & $(0.341)$ \\
Time FE & Yes & Yes & Yes & Yes \\
Country FE & Yes & Yes & Yes & Yes \\
Robust SE & Yes & Yes & Yes & Yes \\
N. of obs. & 1151 & 1151 & 1151 & 1151 \\
R-squared & 0.591 & 0.591 & 0.591 & 0.591 \\
\hline & Panel B: Univariate Statistics-Effectiveness of Matching & \\
\hline Variable & ESG (1) & No-ESG (2) & Difference (1-2) & $p$-values \\
\hline SIZE & 14.552 & 14.546 & 0.006 & 0.797 \\
LIQ & 0.039 & 0.039 & 0 & 0.980 \\
CLAIMS GRW & 0.114 & 0.133 & -0.022 & 0.480 \\
LEV & 0.459 & 0.469 & -0.010 & 0.848 \\
PREMIUM GRW & 0.088 & 0.078 & 0.010 & 0.724 \\
PROFIT & 0.310 & 0.320 & -0.010 & 0.662 \\
\hline
\end{tabular}




$$
\text { D_ESG }=\sum{ }_{k} \beta_{k} \text { FirmControls } i_{i, t-1}+v_{i}+\delta_{t}+\mu_{i, t}
$$

Table A5. Breakdown of sample by country. This table summarizes the number of observations in our sample and their frequency broken down by country.

\begin{tabular}{ccc}
\hline Country & N. of obs. & Frequency \\
\hline Bermuda & 54 & $12.0 \%$ \\
Brazil & 21 & $4.6 \%$ \\
Canada & 35 & $7.8 \%$ \\
Cayman Islands & 1 & $0.2 \%$ \\
Chile & 12 & $2.6 \%$ \\
Jamaica & 3 & $0.7 \%$ \\
Mexico & 15 & $3.3 \%$ \\
Peru & 12 & $2.6 \%$ \\
Trinidad and Tobago & 3 & $0.7 \%$ \\
.United States of America & 298 & $66.0 \%$ \\
\hline Total & 453 & $100.0 \%$ \\
\hline
\end{tabular}

\section{References}

1. Kitzmueller, M.; Shimshack, J. Economic Perspectives on Corporate Social Responsibility. J. Econ. Lit. 2012, 50, 51-84. [CrossRef]

2. Hasan, I.; Kobeissi, N.; Liu, L.; Wang, H. Corporate Social Responsibility and Firm Financial Performance: The Mediating Role of Productivity. J. Bus. Ethics 2018, 149, 671-688. [CrossRef]

3. Revelli, C.; Viviani, J.L. Financial performance of socially responsible investing (SRI): What have we learned? A meta-analysis. Bus. Ethics Eur. Rev. 2015, 24, 158-185. [CrossRef]

4. Brooks, C.; Oikonomou, I. The effects of environmental, social and governance disclosures and performance on firm value: A review of the literature in accounting and finance. Br. Account. Rev. 2018, 50, 1-15. [CrossRef]

5. Fatemi, A.; Fooladi, I.; Tehranian, H. Valuation effects of corporate social responsibility. J. Bank. Financ. 2015, 59, 182-192. [CrossRef]

6. Cheung, A. Corporate social responsibility and corporate cash holdings. J. Corp. Financ. 2016, 37, 412-430. [CrossRef]

7. Gangi, F.; Meles, A.; D’Angelo, E.; Daniele, L.M. Sustainable development and corporate governance in the financial system: Are environmentally friendly banks less risky? Corp. Soc. Responsib. Environ. Manag. 2019, 26, 529-547. [CrossRef]

8. Baradwaj, B.; Dewally, M.; Shao, Y.; Liu, P. Corporate Social Responsibility, Disaster Experience, and Bank Stability. Presented at the 12th Edition of the International Risk Management Conference, Milan, Italy, 17-18 June 2019.

9. Scholtens, B. Corporate Social Responsibility in the International Insurance Industry. Sustain. Dev. 2011, 19, 143-156. [CrossRef]

10. Outreville, J.F. The relationship between Insurance and Economic Development: 85 empirical papers for a review of the Literature. Risk Manag. Insur. Rev. 2013, 16, 71-122. [CrossRef]

11. Sarkis, J.; Dhavale, D.G. Supplier selection for sustainable operations: A triple-bottom-line approach using a Bayesian framework. Int. J. Prod. Econ. 2015, 116, 177-191. [CrossRef]

12. Purvis, B.; Mao, Y.; Robinson, D. Three pillars of sustainability: In search of conceptual origins. Sustain. Sci. 2019, 14, 681-695. [CrossRef]

13. Roman, R.M.; Hayibor, S.; Agle, B.R. The relationship between social and financial performance: Repainting a portrait. Bus. Soc. 1999, 38, 109-125. [CrossRef]

14. Orlitzky, M.; Schmidt, F.L.; Rynes, S.L. Corporate social and financial performance: A meta-analysis. Organ. Stud. 2003, 24, 403-441. [CrossRef]

15. Eccles, R.G.; Ioannou, I.; Serafeim, G. The impact of corporate sustainability on organizational processes and performance. Manag. Sci. 2014, 60, 2835-2857. [CrossRef]

16. Sharfman, M.; Fernando, C. Environmental risk management and the cost of capital. Strateg. Manag. J. 2008, 29, 569-592. [CrossRef] 
17. El Ghoul, S.; Guedhami, O.; Kwok, C.; Mishra, D. Does corporate social responsibility affect the cost of capital? J. Bank. Financ. 2011, 35, 2388-2406. [CrossRef]

18. Attig, N.; El Ghoul, S.; Guedhami, O.; Suh, J. Corporate Social Responsibility and Credit Ratings. J. Bus. Ethics 2013, 117, 679-694. [CrossRef]

19. Albuquerque, R.; Durnev, A.; Koskinen, Y. Corporate Social Responsibility and Asset Pricing in Industry Equilibrium. 2014. Working Paper, SSRN. Available online: https://www.semanticscholar.org/paper/CorporateSocial-Responsibility-and-Asset-Pricing-Albuquerque-Durnev/f5d56b1d3ec31896c171a3f63050bcbc703ddea1 (accessed on 2 June 2020).

20. Becchetti, L.; Ciciretti, R.; Conzo, P. Legal origins and corporate social responsibility. Sustainability 2020, 12, 2717. [CrossRef]

21. Simpson, W.G.; Kohers, T. The link between corporate social and financial performance: Evidence from the banking industry. J. Bus. Ethics 2002, 35, 97-109. [CrossRef]

22. De la Cuesta-González, M.; Muñoz-Torres, M.J.; Fernández-Izquierdo, M.Á. Analysis of social performance in the Spanish financial industry through public data. A proposal. J. Bus. Ethics 2006, 69, 289-304. [CrossRef]

23. Forcadell, F.J.; Aracil, E. European Banks' reputation for corporate social responsibility. Corp. Soc. Responsib. Environ. Manag. 2017, 24,1-14. [CrossRef]

24. Dell'Atti, S.; Trotta, A.; Iannuzzi, A.P.; Demaria, F. Corporate Social Responsibility Engagement as a Determinant of Bank Reputation: An Empirical Analysis. Corp. Soc. Responsib. Environ. Manag. 2017, 24, 589-605. [CrossRef]

25. Maqbool, S.; Zameer, M.N. Corporate social responsibility and financial performance: An empirical analysis of Indian banks. Future Bus. J. 2018, 4, 84-93. [CrossRef]

26. Berger, A.N.; Imbierowicz, B.R.; Rauch, C. The Roles of Corporate Governance in Bank Failures during the Recent Financial Crisis. J. Money Credit Bank. 2016, 48, 729-770. [CrossRef]

27. Anginer, D.; Demirguc-Kunt, A.; Huizinga, H.; Ma, K. Corporate governance of banks and financial stability. J. Financ. Econ. 2018, 130, 327-346. [CrossRef]

28. Waddock, S.A.; Graves, S.B. The corporate social performance-Financial performance link. Strateg. Manag. J. 1997, 18, 303-319. [CrossRef]

29. Brogi, M.; Lagasio, V. Environmental, social, and governance and company profitability: Are financial intermediaries different? Corp. Soc. Responsib. Environ. Manag. 2019, 26, 576-587. [CrossRef]

30. Pasiouras, F.; Gaganis, C. Regulations and soundness of insurance firms: International evidence. J. Bus. Res. 2013, 66, 632-642. [CrossRef]

31. Caporale, G.M.; Cerrato, M.; Zhang, X. Analysing the determinants of insolvency risk for general insurance firms in the UK. J. Bank. Financ. 2017, 84, 107-122. [CrossRef]

32. Gaganis, C.; Hasan, I.; Papadimitri, P.; Tasiou, M. National culture and risk-taking: Evidence from the insurance industry. J. Bus. Res. 2019, 97, 104-116. [CrossRef]

33. International Association of Insurance Supervisors. Issues Paper on Climate Change Risks to the Insurance Sector; IAIS: Basel, Switzerland, 2018.

34. Dowling, G. Reputation risk: It is the board's ultimate responsibility. J. Bus. Strategy 2006, 27, 59-68. [CrossRef]

35. Cummins, J.D.; Weiss, M.A. Analyzing Firm Performance in the Insurance Industry Using Frontier Efficiency and Productivity Methods. In Handbook of Insurance; Dionne, G., Ed.; Series on Risk, Insurance, and Economic Security 22; Springer: Dordrecht, The Netherlands, 2000; pp. 767-829.

36. Anginer, D.; Demirguc-Kunt, A.; Mare, D.S. Bank capital, institutional environment and systemic stability. J. Financ. Stab. 2018, 37, 97-106. [CrossRef]

37. Beck, T.; Laeven, L. Resolution of Failed Banks by Deposit Insurers: Cross-Country Evidence; Policy Research Working Paper Series 3920; The World Bank: Washington, DC, USA, 2006.

38. Demirgüç-Kunt, A.; Huizinga, H. Bank activity and funding strategies: The impact on risk and returns. J. Financ. Econ. 2010, 98, 626-650. [CrossRef]

39. Shim, J. An investigation of market concentration and financial stability in property-liability insurance industry. J. Risk Insur. 2017, 84, 567-597. [CrossRef]

40. Laeven, L.; Levine, R. Bank governance, regulation and risk taking. J. Financ. Econ. 2009, 93, $259-275$. [CrossRef]

41. Li, K.; Griffin, D.; Yue, H.; Zhao, L. How does culture influence corporate risk-taking? J. Corp. Financ. 2013, 23, 1-22. [CrossRef] 
42. Liang, H.; Renneboog, L. On the Foundations of Corporate Social Responsibility. J. Financ. 2017, 72, 853-910. [CrossRef]

43. Bassen, A.; Kovacs, A.M.M. Environmental, social and governance key performance indicators from a capital market perspective. Zeitschrift fur Wirtschafts-und Unternehmensethik 2008, 9, 182-192. [CrossRef]

44. Oikonomou, I.; Brooks, C.; Pavelin, S. The Impact of Corporate Social Performance on Financial Risk and Utility: A Longitudinal Analysis. Financ. Manag. 2012, 41, 483-515. [CrossRef]

45. Adams, M.B.; Burton, B.; Hardwick, P. The determinants of credit ratings in the United Kingdom insurance industry. J. Bus. Financ. Account. 2003, 30, 539-572. [CrossRef]

46. Brotman, B.A. Reliability of best's insurer ratings using financial information published in the annual report. J. Insur. 1989, 12, 58-70.

47. Rosenbaum, P.; Rubin, D. The central role of the propensity score in observational studies for causal effects. Biometrika 1983, 70, 41-55. [CrossRef]

48. Bhandari, A.; Javakhadze, D. Corporate social responsibility and capital allocation efficiency. J. Corp. Financ. 2017, 43, 354-377. [CrossRef]

49. Certo, S.T.; Busenbark, J.R.; Woo, H.S.; Semadeni, M. Sample selection bias and Heckman model in strategic management research. Strateg. Manag. J. 2016, 37, 2639-2657. [CrossRef]

50. Heckman, J.J. Dummy endogenous variables in a simultaneous equation system. Econometrics 1978, 46, 931-959. [CrossRef]

51. Wu, M.W.; Shen, C.H. Corporate social responsibility in the banking industry: Motives and financial performance. J. Bank. Financ. 2013, 37, 3529-3547. [CrossRef]

52. Bharath, S.T.; Dahiya, S.; Saunders, A.; Srinivasan, A. Lending relationships and loan contract terms. Rev. Financ. Stud. 2011, 24, 1141-1203. [CrossRef]

53. Cummins, J.D.; Denenberg, H.S.; Scheel, W.C. Concentration in the U.S. life insurance industry. J. Risk Insur. 1972, 39, 177-199. [CrossRef]

(C) 2020 by the authors. Licensee MDPI, Basel, Switzerland. This article is an open access article distributed under the terms and conditions of the Creative Commons Attribution (CC BY) license (http://creativecommons.org/licenses/by/4.0/). 